\title{
Hint Düşüncesinde İslam Algısı
}

Cemil Kutlutürk

Dergâh Yayınları, İstanbul, 2019, 236 pages.

ISBN 9786052300961

Cemil Kutlutürk, assistant professor in the Divinity School at Ankara University, who works on Hindu religious thought, published a book titled The Perception of Islam in Hindu Thought; A Case Study of Bhakti Movement. The publication offers an intensive study for Turkish readers. The work covers medieval India and elaborates on its political arena, historical atmosphere, and the rigid caste system that was entangled with every part of a Hindu's life. In the Hindu worldview he explains, it was of utmost value to be engaged in the caste system and to live and die in it faithfully. Before the coming of Islam and its spread throughout the Indian subcontinent, both trade and pagan practices served as a uniting force between the two geographically different regions (p. 72). Such encounters between Arabs and Hindus are well documented in historical fragments, oriental travelogues, and remnants of poetry. One could say that this clash of religious and cultural identity was the actual origin of Bhakti movement. In a possible cultural intrusion, there are at least two possibilities: either embracing foreign thought-which was Islam in this case-and celebrating its fruits, or opposing the intruding thought through emphasizing one's own rigid beliefs. Kutlutürk exhibits both phenomena in his present work and explains a third possibility: that of amalgamation, which happened in the form of Bhakti movement in India in the middle ages ( $11^{\text {th }}$ to $17^{\text {th }}$ century).

Kutlutürk elaborates that the Bhakti movement arose from the bottom of Hindu social hierarchy. It was the lowest casts of Shudras and Dalits who adopted the concepts of equality, equity, and a singular God from the newcomers in the region. These newcomers were Muslims by faith and, for the most part, Central Asian Turks. The author claims that titles and terms which were used during that period for Turks and Muslims could be understood synonymously as both were labelled as outlaws, Yavana Dharma, or people without ear piercings, Aviddhan (p. 115).

In this work, Kutlutürk introduces the original Sanskrit and Arabic primary sources for his research, in addition to English, Urdu, and Hindi secondary sources which could be a depository for new researchers in the field. Even though the author confines himself to the principal sources of 
Bhakti movement, he is well aware of the linguistic difficulties, since the movement was initiated in southern India and then prevailed throughout the Indian subcontinent for centuries. Its major poetry and texts developed in indigenous languages such as Tamil, Telugu or Marathi and Rajasthani, with native symbolism making it very difficult for an amateur researcher to comprehend. Kutlutürk acknowledges these challenges and therefore depends upon Urdu and English translations (p. 259). It is mentioned that the sole purpose of the book is to detail the historical context in which Islam arrived, Muslims were addressed, and how Turks were understood in the medieval Indian milieu. The work also mentions the background of polemical refutations from Hindu intelligentsia at times against the Muslims (p. 14).

Kutlutürk asserts that Hindu scholars, for the most part, did not consider a thorough study of Islam worthy; hence their critiques are full of misconceptions and generalizations (p. 18). He follows the footsteps of Bhakti movement from southern India (Tamil Nadu) to the northern Himalayas. Within three major sects of Hinduism-Vaishnavism (Vishnu), Shaivism (Shiva), Shaktism (Devi) - Kutlutürk establishes Vaishnavism as being widely practiced in medieval India (p. 33). After offering a brief exposition of Hindu sects he elaborates on the philosophical landscapes of the time.

Two important schools of thoughts were Advaita Vedanta and Vishisht Advaita, both within the fold of Hinduism. People who believed in the former considered the human soul to be of the same essence as the God Brahman. On the other hand, the later school of Vedanta philosophy claimed Brahma God to be the only true existence and the rest of creation merely His infinite reflection in multiplicity. Both schools held some variation of monistic attitude. Likewise, the dynamic Nath movement appeared at the Indian thought stage. Nath, who was also called as Natha, was a Shaivist sub-tradition within Hinduism. This ascetic movement, Kutlutürk expresses, amalgamated the ideas from Buddhism, Shaivism, and Yogi traditions of India (p. 39). Such syncretic belief systems were highly philosophical; many adherents practiced celibacy and had ecstatic tendencies. These practices were most prominent in their bodily piercings of their nose or ears as a sign of renunciation of the world, Kanphata Jogi (p. 40). Naths, on one hand, developed out of syncretism; yet at the same time, they showed serious devotion to their approach and spent a carefree life from established religions. Kutlutürk argues that their thought became a fine link between a strict Hindu religious structure and the Bhakti movement. This is why one could find multitudes of commonalities between works of Gorakhnath, 
Ravidas (1398-1540), Kabir (1440-1518), and Nanak (1469-1539). Kutlutürk claims that they had as a basic tenet rebellion against the caste system, and a deep urge for the unification of religious mindset through belief in one supreme, all-loving deity.

Bhakti was also one of these syncretic movements; as such, unlike Hindus or Muslims, adherents believed in salvation for everyone regardless of their race, color or faith. They believed in a transnational deity who is all loving and companionate. Kutlutürk also marks the apparent signs of mockery of Islam, Muslims or Turks, since Bhaktis were rebellious in their spirit and ridiculed the dogmatic social hierarchy (p. 46).

The first chapter, "Muslims and Islam in India," covers the historical relationship between Muslims as foreigners and India as a land of conquest. Since the advent of Islam and later during the caliphate period, India was neither a forgotten land nor a country to be besieged. In the Abbasid era, around $712 \mathrm{CE}$, the first military troops were sent to Sind. However, it was Mahmud of Ghazni from the house of Ghaznavids, who attacked India from the west consecutively and ruled over the western regions. The author here addresses the Muslim Indian rule in quite a cursory manner, covering almost eight centuries. Since the book does not primarily concern history, such a surface overlook is perhaps intended to help the reader understand the Bhakti movement in its context. Nevertheless, such an excuse for avoiding details might leave a reader puzzled. For instance, Kutlutürk states, "Sultan of Ghazna (d. 1030) built mosques in the newly gained region and founded madrasas. He invited Muslim scholars from different regions to propagate Islam..." (p. 52), whereas in the next paragraph he specifies that Mahmud also weakened the Fatimid (Shia) approach and zealously imposed a Sunni and Hanafi mindset over his subjects. The term Islam in this context seems vague, especially when it comes to Sultanate of Delhi or the emperors of the Mughal throne. Each ruler had his political policy for which religion was intensely invoked. For instance, unlike Mahmut of Ghazna, it was Akbar shah of the Mughal Empire whose politics of Sulh-I Kul (a wave of peace for all) made it possible for India to prosper on secular grounds. Akbar, a Muslim ruler too, in his new code of state, made it permissible for people to enjoy religious freedom. He made it obligatory for the state to treat all its subjects equally regardless of their faith or racial ethnicity (p. 68). Since the study is confined to medieval India, the book mentions Hindu ruling elites in juxtaposition to Muslim rule of the Rajpoots, Pala, Maratha, Vijayanagar, and Chalukya empires along with Buddhists tensions of the period. 
The second chapter, "Muslims and Islam in medieval Hindu sources," begins with a broad understanding of Hindu wisdom (Vedas) and how it had polarized society into the rigid caste system. In such a closed culture, Kutlutürk argues a newcomer was considered as an outlier with no place in Indian social fabric. For evidence, he later mentions the terms and titles that were used in medieval Hindu texts for Islam, Muslims, and Turks, making for quite an interesting study into linguistic development. Kutlutürk maintains that words such as Amir or Sultan were Indianized through terms like Hami$r a$ and Suratana. However, he claims that such titles were not always used as neutral terms but with partial prejudice. This is because Hindus within the periphery of their scriptures and culture considered their historical narrative ultimate and the land sacred. Consequently, those who do not practice or live their faith as Veda says are of no value, Mleccha (p. 135). Muslims, who lacked Vedic wisdom and showed no interest in the caste system, stirred these tensions on a deeper level.

The book gives a clear outline of beliefs in medieval India, and shows how they were instrumentalized for creating an 'us versus them' solidarity shift. For instance, the book refers to the revivalist Hindu texts claiming that the arrival of Muslims at the Indian shores marked the beginning of the final era of humanity-Kal yoga, or the apocalyptic phase (p. 144). Regardless of this, Kutlutürk expounds, the negative view of Muslims and Islam in medieval Indian thought was encouraged by the religious and political elite who shaped and led the Hindu society. Likewise, the targets of their accusations were the Muslim rulers, rather than the masses, who did not approve of their political and religious policies. (p. 145)

He further asserts that because Turks were the first Muslims who Indians encountered, Turkic ethnic groups became synonymous with being Muslim. Hindus, like people from other closed cultures, recognized minor differences and labeled them as unknowns (p. 146). They surely knew what a good and just leadership might look like. This was why they admired many Muslim Turkish rulers for their governance and statesmanship (p. 151). Kutlutürk insists that foreigners, whether traders or invaders, were not accustomed or familiar with the Hindu caste system or social stratification.

The third and final chapter deals with Islam, Muslims, and Turks in Bhakti thought. Bhakti means "to be of service, to love, share or devote oneself and be companionate"; as the name suggests, this movement advocated that the actual message of Purana, Gita or Quran is encrypted in love. Apart from sadhus and gurus in later periods, such as the aforementioned Kabir or Nanak, Ramananda, the pioneering figure of the movement, expressed his belief in 
one God and rejected the linguistic supremacy of Sanskrit as a divine language. Likewise, new devotees followed his path and wrote extensively in local languages, utilizing indigenous expressions and taking God away from the Brahman monopoly, thereby making Him accessible for masses. Further, the Bhakti movement is distinguished in its rejection of Hindu Soteriology, which left no space for lower castes or non-Hindu religions. One could say confidently that Bhakti was a revolutionary thought which claimed equality for every person in the eyes of God and an equal share in the bliss of salvation, regardless of race, gender, color or creed (p. 188). The book eloquently sheds light on such issues giving possible explanations for the popularity of the movement through the present day.

For a Bhakt (a devotee or follower of Bhakhti movement), Kutlutürk explains, it was more important how much love one had for God and other people rather than what caste he was born into. It is interesting to note that a devotional de-religious movement developed its own Bhakti Marga; a format of enchanting and ascetic practices. One could observe how an initial rift within a system ended up forming a new configuration and identity boundaries.

The Sufi Muslim tradition, whether from Central Asia or Persia, was infused in Indian cultural life, influencing the Bhakti movement in significant ways. This is why in the Bani genre of Bhakti poetry Arabic and Persian words appear along with Pali, Hindi or Marathi. Kutlutürk clarifies that Hindus were also marginalized by Muslims for being pagan and polytheist. Bhakti held that strictly ritual manners of Muslims could never reflect the true essence of Islam. They also opposed the clergymen being Pandit or Imams because their actions were viewed as problematic as long as they did not consider every individual worthy of salvation. In this regard, Bhakti helped to resolve the opposing religions. No doubt, Bhakti emerged as a multi-religious brotherhood; their political thought remained in the shadows. This played a pivotal role in the Muslim imagery of medieval India.

The movement was a true mosaic of poets, practitioner yogis, ascetics, and leaders. One could say that these forerunners rejected the truth of any single religion. However, on deeper analysis, it is evident that rather than opposing religion, they had a desire to unify around the core values of collective peace and spiritual prosperity.

By reading this book, a Turkish reader gets a preview of medieval India along with a concise narrative of Hindu history. Perhaps one could find a 
refined understanding of Hindu-Muslim relations that will prove helpful in promoting dialogue and in understanding contemporary religious conflicts. This book is an important contribution to the Turkish academy as it not only reveals the aftermath of the Muslim arrival to India but also evaluates it on religious, cultural, and moral grounds. Reading this, enthusiastic scholars are likely to enhance their knowledge of India studies.

Abdul Basit Zafar, Ph.D Student Ankara University Divinity School ORCID 0000-0003-0840-5865 DOI 10.26570/isad.650338 